\title{
Circulating Antimicrobial Peptide LL-37 Status in Type 1 Diabetes Mellitus and its Relation with Glycemic Control
}

\author{
Himika Chawla ${ }^{\prime}$, Parmita Kar ${ }^{l}$, Soma Saha ${ }^{1}$,Urvashi B. Singh ${ }^{2}$, Nikhil Tandon ${ }^{\prime}$, R. Goswami ${ }^{l}$ \\ Department of Endocrinology and Metabolism ${ }^{1}$, Department of Microbiology ${ }^{2}$, \\ All India Institute of Medical Sciences, New Delhi, India.
}

\begin{abstract}
Antimicrobial-peptides are important molecules of constitutive innate immunity. Though patients with diabetes mellitus are generally prone to infections, there is limited information on their antimicrobialpeptide status. We assessed the circulating LL-37 antimicrobial peptide (also referred as cathelicidin) levels in patients with type 1 diabetes mellitus and its relation with their glycemic status. The LL-37 mRNA expression was assessed in the peripheral blood mononuclear cells (PBMC) by quantitative RTPCR using $\beta$-actin and cytochrome- $C 1$ as the reference genes in 154 subjects (Type 1 diabetes, $\mathrm{n}=111$ and healthy subjects, $n=43$ ). Serum LL-37 was quantified using sandwich-ELISA. Average HbA1c over last 2 years and current $\mathrm{HbA} 1 \mathrm{c}$ were used to determine long-term and short-term glycemic status. LL-37 mRNA expression and serum LL-37 levels were correlated with the glycemic status. The LL-37 mRNA copies were comparable between type 1 diabetes and healthy subjects [median (IQR) $=6.7$ $(1.8-15.28)$ vs. 7.2 (2.23-21.86), respectively, $\mathrm{P}=0.42$ ]. There was no significant difference in serum LL-37 levels between the two groups [median $(I Q R)=3.9(2.88-7.52)$ vs. $5.0(3.19-9.05) \mathrm{ng} / \mathrm{ml}$, respectively, $\mathrm{P}=0.52]$. The LL-37 $\mathrm{mRNA}$ and its protein concentration showed no significant correlation with the average or current $\mathrm{HbAlc}$ values. The constitutive circulating antimicrobial peptide LL-37 status is not significantly altered in patients with type 1 diabetes mellitus and also not affected by their glycemic status.
\end{abstract}

Keywords: Innate-immunity, diabetes mellitus, antimicrobial peptide LL-37, cathelicidin, glycosylated hemoglobin.

\section{Introduction}

Recurrent bacterial and fungal infections of genitourinary tract, skin, and lungs are common in patients with type 1 diabetes mellitus (T1DM) (1-3). The reasons of increased susceptibility to infections in diabetes are not clear but could involve hyperglycemia mediated abnormalities in innate immunity involving polymorphonuclear cell dysfunction and various antimicrobial peptides (4-5). The LL-37 antimicrobial peptide (cathelicidin) is an essential component of the innate immunity. It is produced by several cells such as leukocytes, keratinocytes and mucosal epithelial cells to promote phagocytosis in macrophages, dendritic cell differentiation, chemokine production, keratinocyte migration and wound healing. LL37 also inhibits apoptosis of leukocytes and biofilm formation (6-9).

Though there is increasing interest in the role of LL-37 in bacterial infections, HIV and tuberculosis, the information on LL-37 expression in diabetes is limited. Since patients with uncontrolled diabetes may be particularly

Correspondence : Dr. Ravinder Goswami, MD, DM (Endocrinology), Department of Endocrinology and Metabolism, All India Institute of Medical Sciences, New Delhi-110029, India. Email: gosravinder@hotmail.com.Phone:91-11-26594272. 
prone to infections, LL-37 expression might be altered in them (10-13). Earlier studies involving limited number of patients showed variable status of LL-37 in diabetes. Gonzales et al and Santiago et al reported reduced LL-37 mRNA expression in circulating leukocytes in DM and peri-ulcer skin biopsy of patients with diabetic foot, respectively $(11,12)$ and Brauner et al showed reduced LL-37 levels in T1DM as compared to patients with type 2 diabetes (13). The relationship of glycemic control with circulating LL-37 has not been studied till date. Present study investigated LL-37 mRNA expression in peripheral blood mononuclear cells (PBMC) and serum LL-37 concentration in a cohort of 111 patients with T1DM and assessed its relation with their glycemic status.

\section{Materials and Methods}

The study included 111 patients with T1DM attending 'Diabetes of young' clinic at the All India Institute of Medical Sciences, Delhi. Pregnant, lactating women and patients with overt bacterial infections were excluded. Their details including age at onset of diabetes, nephropathy, retinopathy, pulmonary tuberculosis and serial $\mathrm{HbAlc}$ values during previous two years were noted from clinical records. Forty three healthy subjects with normal $\mathrm{HbA} 1 \mathrm{c}$ who consented for the study were included for comparison.

\section{Quantitative Real Time Reverse Transcription PCR (qRT-PCR) for LL-37 mRNA Expression}

Ten $\mathrm{ml}$ blood was collected in fasting state in nuclease-free heparinized tube for isolating PBMC by Ficol and RNA extraction using Trizol (Invitrogen, Carlsbad) (14). RNA was quantified using UV spectrophotometer (GeneQuant, Amersham) and its quality was assessed by agarose gel electrophoresis and RNA integrity number (Bio-analyser 2100, Agilent Technologies Inc.). First strand of cDNA was prepared using $2.0 \mu \mathrm{g}$ of total RNA, random hexamer nucleotides and $\mathrm{M}-\mathrm{MuLv}$ reverse transcriptase in $20 \mu 1$ reaction incubated at $25^{\circ} \mathrm{C}$ for $10 \mathrm{~min}$ followed by $42^{\circ} \mathrm{C}$ for 1 hour (14).

The qRT-PCR for LL-37 mRNA was carried out using SYBR-mix (Biorad, Hercules, USA) in CFX96 cycler (Bio-Rad) in $20 \mu 1$ reaction using LL-37 gene-specific primers (sense-5'gcggtggtcactggtgctcctgctgct 3' and antisense-5'gaagaaatcacccagcagggcaaatc 3 ') (14). The RNA expression of housekeepinggenes ( $\beta$-actin and cytochrome $C 1)$ was used as control. The sense and antisense primers for $\beta$ actin (5'catgtacgttgctatccaggc 3' and 5'ctccttatgtcacgccacgat3') and cytochrome C1 ( 5 'agctgccaacaacggagcat 3' and 5'gactgaccacttgtgccgct3') were designed using - P r i m e r - 3 - s o f t w a r e (http://www.ncbi.nlm.nih.gov/tools/primerblast). The PCR conditions were $94^{\circ} \mathrm{C} \times 3 \mathrm{~min}$, 39 cycles of $94^{\circ} \mathrm{C} \times 30 \mathrm{~s}, 55^{\circ} \mathrm{C}$ for $\beta$-actin and $60^{\circ} \mathrm{C}$ for LL-37 and cytochrome $C 1$ each $x 30 \mathrm{~s}$, $72^{\circ} \mathrm{C}$ x $30 \mathrm{~s}, 86^{\circ} \mathrm{C}$ x $20 \mathrm{~s}$, final extension $72^{\circ} \mathrm{C}$ x $10 \mathrm{~min}$. The intra-assay and inter-assay variation were $0.9-1.7 \%$ and was $3-5 \%$, respectively. All the reactions were performed in duplicates, and specificity of amplified products was checked by post-PCR melt-curve analysis and agarose gel electrophoresis (Fig.1). The specificity of amplified products of LL-37 was checked by DNA sequencing and that of $\beta$ actin and cytochrome $C 1$ by RFLP using Eco0109I and TaqI restriction enzymes, respectively. The mRNA copy number of LL-37 was determined per $10^{3}$ copies of geometric mean of $\beta$-actin and cytochrome $C 1$.

\section{ELISAfor Serum LL-37 Concentrations}

A sandwich ELISA with LL-37 specific antibody precoated on to 96 well microplate was used (MyBiosource Inc., USA). Briefly, blood was allowed to clot at room temperature, centrifuged at $1000 \mathrm{xg}$ for 15 minutes at $4^{\circ} \mathrm{C}$ and serum was stored at $-80^{\circ} \mathrm{C}$. Assay was carried out using $100 \mu \mathrm{l}$ of serum along with seven standards ranging from 1.56-100 ng/ml. AvidinHRP was used in conjunction with biotinylated 
(A)
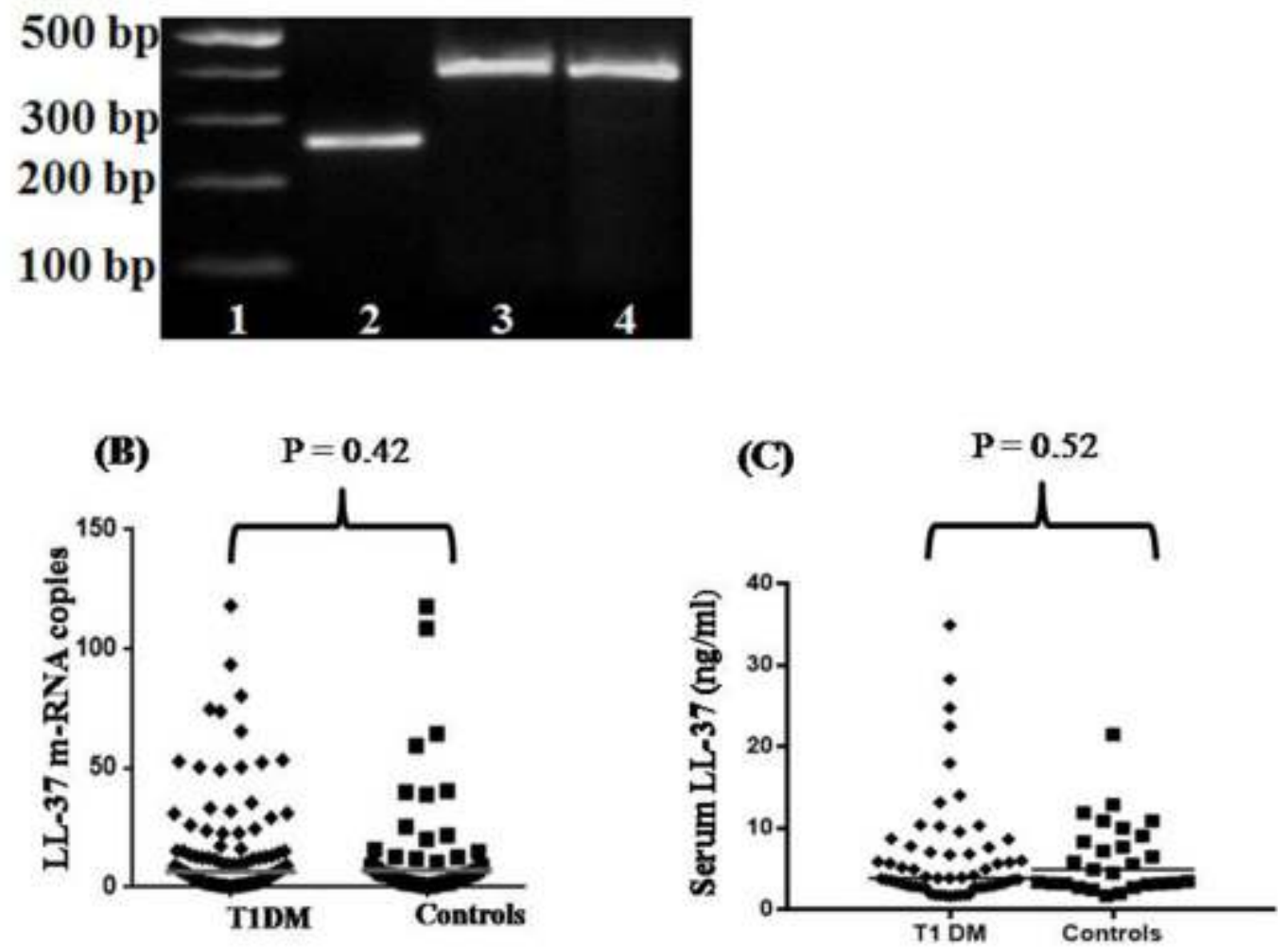

Fig.1: Agarose gel (1.5\%) electrophoresis showing the PCR products of $\beta$-actin, CYC1 and LL-37 (lanes 2,3,4, respectively), Lane 1: 100 bp DNA ladder (A); LL-37 expression in T1DM and controls, mRNA copies $/ \mathbf{1 0}^{3}$ reference genes $(B)$ and serum $L L-37$ concentration $(C)$

detection antibodies as second step reagent for indirect enzymatic labeling. Serum samples from patients and healthy subjects were put in the ELISA plates in 2:1 ratio to minimize assayrelated variation. The ELISA was carried out as per the kit protocol with optical density measured at a wavelength of $450 \mathrm{~nm}$ using iMark reader (Biorad). The specific absorbance was plotted by four-parameter logistic curve fitting. The assay had minimum detection limit of $0.94 \mathrm{ng} / \mathrm{ml}$ of natural and recombinant LL-37, coefficient of variation $<10 \%$ and reportable range between $1.56-100.0 \mathrm{ng} / \mathrm{ml}$.

The study was approved by the Institutional Ethics Committee of All India Institute of Medical Sciences, New Delhi. Written informed consent was obtained from all subjects.

\section{Statistical Analysis}

Data are shown as mean $\pm \mathrm{SD}$, frequencies and median with interquartile range. The differences in the study parameter between patients with diabetes and healthy subjects were compared using Student's 't' test or by Mann' Whitney 'U' test as appropriate. Differences in the frequency of subject with serum LL-37 value below the detection range of the assay $(<1.56$ $\mathrm{ng} / \mathrm{ml}$ ) between diabetes and controls were analyzed using chi Square test. Pearson's correlation coefficient was used to assess relationship between LL-37 mRNA expression with average HbA1c over last two years and current $\mathrm{HbA} 1 \mathrm{c}$. Similar analysis was also carried out for serum LL-37. All the statistical analyses were implemented on SPSS 11.5 (SPSS Inc., USA). A two-tailed $\mathrm{P}$ value of $<0.05$ was considered significant. 


\section{Results}

Table 1 shows the clinical and biochemical characteristics of the study subjects. The mean age and male: female ratio of patients $(28.6 \pm$ 11.68 years and 56:55) and healthy subjects (29.6 \pm 5.86 years and 23:20) were comparable. The mean BMI was significantly less in the diabetes group than healthy subjects $(20.6 \pm 4.0$ $\mathrm{kg} / \mathrm{m}^{2}$ and $25.1 \pm 2.79 \mathrm{~kg} / \mathrm{m}^{2}$, respectively, $\mathrm{P}$ $<0.001)$. The mean HbAlc was higher in diabetes than healthy subjects $[9.2 \pm 1.98 \%(77.1$ $\pm 21.78 \mathrm{mmol} / \mathrm{mol})$ and $5.4 \pm 0.33 \%(35.1 \pm 3.62$ $\mathrm{mmol} / \mathrm{mol}), \mathrm{P}<0.001]$. The mean duration of diabetes was $15.4 \pm 9.12$ years and history of diabetic ketoacidosis was present in $76(68 \%)$ patients. $\mathrm{GAD}_{65}$ auto-antibodies were positive in $58.6 \%$ of the 87 patients tested. Retinopathy and proteinuria $>150 \mathrm{mg} / 24$ hours were present in $22.5 \%$ and $5.4 \%$, respectively. The mean hemoglobin and leukocyte counts were in normal range in both patients and healthy subjects.

\section{LL-37 mRNA Expression and its Serum Concentration in Diabetes}

The mean LL-37 mRNA expression was comparable between diabetes and healthy groups. In view of the skewed distribution of LL37 mRNA expression, the two groups were compared using non-parametric test. There was no difference in the median copy number of LL37 mRNA) between the two groups (Table 1). The median serum LL-37 protein concentration were comparable between diabetes and healthy subjects $[$ median $(\mathrm{IQR})=3.9(2.88-7.52)$ vs. 5.0 (3.19-9.05) ng/ml, respectively, $\mathrm{P}=0.52]$. Similarly, the frequency of subjects with serum LL-37 below the detection range were comparable between diabetes and control groups $(45.9 \%$ vs. $37.2 \%$, respectively, $\mathrm{P}=0.42)$.

Table 1: Clinical and biochemical characteristics of study subjects

\begin{tabular}{|c|c|c|c|c|}
\hline Parameter & $\begin{array}{c}\text { Diabetes } \\
(\mathbf{n}=111)\end{array}$ & $\begin{array}{l}\text { Healthy subjects } \\
\qquad(\mathrm{n}=43)\end{array}$ & $\begin{array}{l}t \text { and } U- \\
\text { values }\end{array}$ & $\mathbf{P}$ \\
\hline Age (years) & $28.6 \pm 11.68$ & $29.6 \pm 5.86$ & $\mathrm{U}=2152.0$ & 0.35 \\
\hline Male: Female (n) & $56: 55$ & $23: 20$ & - & 0.86 \\
\hline Body mass index $\left(\mathrm{kg} / \mathrm{m}^{2}\right)$ & $20.6 \pm 4.00$ & $25.1 \pm 2.79$ & $\mathrm{U}=803$ & $<0.001$ \\
\hline $\mathrm{HbA1c}(\mathrm{mmol} / \mathrm{mol})$ & $77.1 \pm 21.78$ & $35.1 \pm 3.62$ & $\mathrm{U}=1.0$ & $<0.001$ \\
\hline Total leukocytes (count $/ \mathrm{mm}^{3}$ ) & $7462 \pm 1920$ & $7039 \pm 2041$ & $\mathrm{t}=1.2$ & 0.24 \\
\hline Polymorphs (\%) & $59.1 \pm 9.71$ & $58.7 \pm 6.05$ & $\mathrm{U}=1051$ & 0.98 \\
\hline Lymphocyte (\%) & $30.4 \pm 8.47$ & $29.9 \pm 4.14$ & $\mathrm{U}=1014$ & 0.79 \\
\hline Erythrocyte sedimentation rate $(\mathrm{mm} / \mathrm{hr})$ & $17.6 \pm 13.36$ & $15.7 \pm 9.3$ & $\mathrm{U}=2333$ & 0.90 \\
\hline $\begin{array}{l}\text { LL-37 mRNA } / 10^{3} \text { housekeeping copies } \\
\text { Median (IQR) }\end{array}$ & $6.7(1.8-15.28)$ & $7.2(2.23-21.86)$ & $U=2186$ & 0.42 \\
\hline Serum LL-37 (ng/ml) Median (IQR) & $\begin{array}{l}3.9(2.88-7.52) \\
(\mathrm{n}=60)\end{array}$ & $\begin{array}{l}5.0(3.19-9.05) \\
(\mathrm{n}=27)\end{array}$ & $\mathrm{U}=740.5$ & 0.52 \\
\hline
\end{tabular}




\section{Correlation of LL-37 mRNA Expression and Serum LL-37 Protein with Glycemic Status}

The LL-37 mRNA expression showed no significant correlation with the current $\mathrm{HbA} 1 \mathrm{c}$ $(\mathrm{r}=-0.014, \mathrm{P}=0.88)$ and the average HbAlc during previous two years $(\mathrm{r}=0.105, \mathrm{P}=0.27)$. Similarly, there was lack of significant correlation between the serum LL-37 concentration and current $\mathrm{HbA} 1 \mathrm{c}(\mathrm{r}=0.05, \mathrm{P}=$ $0.72)$ and average $\mathrm{HbAlc}(\mathrm{r}=0.03, \mathrm{P}=0.83)$.

Eleven of 111 T1DM patients had M.tb positive sputum culture. The LL-37 mRNA expression and its serum concentration showed no significant differences between patients with and without sputum culture positive for M.tb.

\section{Discussion}

The reasons of susceptibility to infections in patients with diabetes and their relation to hyperglycemia are under investigation (7-9, 1517). Antimicrobial peptides are a key component of the first and second layer of defense of the body. Its presence in the skin and mucosal epithelial barrier supplement the first layer of defense. Polymorphonuclear cells secreting LL37 pass through various compartments of the body to provide defense against various pathogenic organisms $(9,18)$. Recently, there has been interest in the altered expression of circulating LL-37 in diabetes $(11,13)$. However, results have been variable, which could be due to the limited number of subjects in these studies $(11,13)$. The present study has been carried out to assess possible alteration in the LL-37 expression among patients with diabetes. The strength of the study are a large cohort of patients with T1DM, age matched healthy subjects, measurement of both mRNA expression and serum LL-37 concentration and the availability of HbA1c data of patients during previous two years.

The present study showed no significant alteration in the LL-37 mRNA expression and circulating LL-37 protein concentration in patients with diabetes. Interestingly, both LL-37 mRNA and LL-37 protein concentration also showed no significant relationship with current or average HbA1c indicating that circulating LL-37 expression is not altered with severity of hyperglycemia. There have been only two previous studies reporting mRNA expression in the PBMC and serum concentration of LL-37 in patients with diabetes. Gonzalez et al reported significantly lower mRNA expression of LL-37 in 30 patients with T2DM compared to healthy subjects $(\mathrm{P}<0.001)(11)$. Brauner et al assessed the serum concentration of LL-37 in 58 patients with diabetes (27 T1DM and 31 T2DM) and 19 healthy subjects (13). The study revealed significantly lower serum LL-37 concentration T1DM compared to those with T2DM. However, the LL-37 levels among patients with T1DM were comparable to the control group. Interestingly, in the current study we did not find any significant difference in LL-37 expression between patients with and without sputum M.tb positivity. These preliminary findings need to be further assessed in future studies targeting larger cohort of diabetes patients with and without active tuberculosis.

Thus, the lack of significant difference in the serum LL-37 concentration between patients and healthy subjects in current study coupled with no significant relationship of LL-37 with glycemic control suggest that constitutive LL-37 expression is not altered in patients with diabetes at least in the circulation. Further, the expression of LL-37 peptide is not affected by adverse glycemic status in patients with T1DM.

\section{Funding}

The study was partially funded by Endocrine Society of India as research grant for carrying out post doctoral thesis of Dr. Himika Chawla (Grant No. ESI2015-DMT01).

\section{Declaration of Interest}

The authors have nothing to disclose and there is no conflict of interest. 


\section{Acknowledgements}

The authors acknowledge the help of Ms. Rimpy Rana and Mr. Arun Chandran, Technicians, Department of Endocrinology, AIIMS, New Delhi, in RNA extraction.

\section{Ethics}

The study was carried out after approval from the Ethics Committee of the All India Institute of Medical Sciences, New Delhi (Reference IESC/T-296/08.08.2014 vide letter 23-8-2014). Written informed consent was obtained from all the patients and controls.

\section{References}

1. Shah BR, Hux JE (2003). Quantifying the risk of infectious diseases for people with diabetes. Diabetes Care 26 :510-513.

2. Muller LM, Gorter KJ, Hak E, et al (2005). Increased risk of common infections in patients with type 1 and type 2 diabetes mellitus. Clin Infect Dis 41 :281-288.

3. Goswami R, Dadhwal V, Tejaswi S, et al (2000). Species-specific prevalence of vaginal candidiasis among patients with diabetes mellitus and its relation to their glycaemic status. J Infect 4 :162-166.

4. Casqueiro J, Casqueiro J, Alves C (2012). Infections in patients with diabetes mellitus: A review of pathogenesis. Indian $J$ Endocrinol Metab 16(S1): S27-S36.

5. Geerlings SE, Hoepelman AI (1999). Immune dysfunction in patients with diabetes mellitus. FEMS Immunol Med Microbiol 26 : 259-265.

6. Vandamme D, Landuyt B, Luyten W, Schoofs L (2012). A comprehensive summary of LL-37, the factotum human cathelicidin peptide. Cell Immunol 280 : 22-35.
7. Torres-Juarez F, Cardenas-Vargas A, Montoya-Rosales A, et al (2015). LL-37 immunomodulatory activity during mycobacterium tuberculosis infection in macrophages. Infect Immun 83 : 44954503.

8. Nilsson MF, Sandstedt B, Sorensen O, Weber G, Borregaard N, Backdahl MS (1999). The human cationic antimicrobial protein (hCAP-18), a peptide antibiotic, is widely expressed in human squamous epithelia and co-localizes with interleukin-6. Infect Immun 67 : 25612566.

9. Dürr UH, Sudheendra US, Ramamoorthy A (2006). LL-37, the only human member of the cathelicidin family of antimicrobial peptides. Biochim Biophys Acta 1758 : 1408-1425.

10. Tangpricha V, Judd SE, Ziegler TR, et al (2014). LL-37 concentrations and the relationship to vitamin $\mathrm{D}$, immune status, and inflammation in HIV-infected children and young adults. AIDS Res Hum Retroviruses 30 : 670-676.

11. Gonzalez-Curiel I, Castañeda-Delgado J, Lopez-Lopez N, et al (2011). Differential expression of antimicrobial peptides in active and latent tuberculosis and its relationship with diabetes mellitus. Hum Immunol 72 : 656-662.

12. Rivas-Santiago B, Trujillo V, Montoya A, et al (2012). Expression of antimicrobial peptides in diabetic foot ulcer. J Dermatol Sci 65 : 19-26.

13. Brauner H, Lüthje $\mathrm{P}$, Grünler $\mathrm{J}$, et al (2014). Markers of innate immune activity in patients with type 1 and type 2 diabetes mellitus and the effect of the antioxidant coenzyme Q10 on inflammatory activity. Clin Exp Immunol 177 : 478-482. 
14. Das M, Tomar N, Goswami R, Sreenivas V, Gupta N (2014). Effect of vitamin D supplementation on cathelicidin, IFN- $\gamma$, IL-4 and Th1/Th2 transcription factors in young healthy females. Eur J Clin Nutr $\mathbf{6 8}$ :338-343.

15. Peleg AY, Weerarathna T, Mc-Carthy JS, Davis TM (2007). Common infections in diabetes: pathogenesis, management and relationship to glycaemic control. Diabetes Metab Res Rev 23 : 3-13.

16. Rodacki M, Svoren B, Butty V, et al (2007). Altered natural killer cells in type 1 diabetic patients. Diabetes 56 : 177-185.
17. Delamaire $\mathrm{M}$, Maugendre $\mathrm{D}$, Moreno $\mathrm{M}$, Le Goff MC, Allannic H, Genetet B (1997). Impaired leucocyte functions in diabetic patients. Diabetic Med 14 : 29-34.

18. Nijnik A, Hancock RE (2009). The roles of cathelicidin LL-37 in immune defenses and novel clinical applications. Curr Opin Hematol 16 : 41-47. 